\title{
Synthesis and Structure Characterization of 2-(Dimethylaminomethyl)pyrrolate and 2,5-Bis(dimethylaminomethyl)pyrrolate Zirconium Complexes
}

\author{
Jui-Hsien Huang $*^{\text {a }}($ \\ Gene-Hsiang Lee ${ }^{\mathrm{b}}$ \\ ), Pei-Cheng Kuo a ( \\ ) and Shie-Ming Peng ${ }^{\mathrm{b}}($ \\ ) \\ ) \\ ${ }^{a}$ Department of Chemistry, National ChangHua University of Education, Changhua 500, Taiwan \\ ${ }^{\mathrm{b}}$ Department of Chemistry, National Taiwan University, Taipei 106, Taiwan
}

\begin{abstract}
Tetrakis(diethylamido)zirconium reacts with 2-(dimethylamino)methyl pyrrole (DMAMP) and 2,5-[bis(dimethylamino)methyl]pyrrole (BDMAMP) to give $\mathrm{Zr}(\mathrm{NEt})_{2}(\mathrm{DMAMP})_{2} \mathbf{1}$ and $\mathrm{Zr}(\mathrm{NEt})_{3}(\mathrm{BDMAMP}) \mathbf{2}$, respectively. Both 1 and $\mathbf{2}$ have been characterized by ${ }^{1} \mathrm{H}$ and ${ }^{13} \mathrm{C}$ NMR spectroscopies and $\mathbf{1}$ has also been characterized by X-ray crystallography. Complex 1 shows an agostic interaction between $\mathrm{Zr}$ and $\mathrm{H}(21 \mathrm{~A})$ in solid state that is not sustained in solution. Reacting 1 with 2 equivalents of trimethylsilyl chloride in toluene yields $\mathrm{ZrCl}_{2}$ (DMAMP) 3 in $75 \%$ yield which was characterized by ${ }^{1} \mathrm{H}$ and ${ }^{13} \mathrm{C}$ NMR spectroscopies.
\end{abstract}

\section{INTRODUCTION}

Metal complexes regarding the catalytic activity, stereoregularity and the extent of branching of olefin polymerization can be fine-tuned by varying metals and substituted ligands. It is well known that the early transition metals have been used intensively as catalysts, such as Ziegler Natta catalysts and metallocene catalysts, ${ }^{1}$ for $\alpha$-olefin polymerization. Among these catalysts, cyclopentadienyl systems are the most common ligands used for synthesizing metal complexes. However, non-cyclopentadienyl systems, such as mono, bidentate, and/or multidentate alkoxides ${ }^{2}$ and amide ${ }^{3}$ ligands have attracted much attention in the past decades; for example, the iminophosphonamide complexes, ${ }^{4}\left[\mathrm{R}_{2} \mathrm{P}\left(\mathrm{NR}^{\prime}\right)_{2}\right]_{2} \mathrm{ZrCl}_{2}$ $(\mathrm{R}=\mathrm{Ph})$, reported by Collins reveal higher reactivity than metallocene systems and oxo bridged zirconium tridentate diamide complexes ${ }^{5}\left[\left(\left(t-\mathrm{Bu}-d_{6}\right) \mathrm{N}-o-\mathrm{C}_{6} \mathrm{H}_{4}\right)_{2}\right] \mathrm{ZrMe}_{2}$ reported by Schrock exhibit living $\alpha$-olefin polymerization. The new types of olefin polymerization catalysts beyond metallocene have been reviewed recently by Gibson et al. ${ }^{6}$ Besides the alkoxide and amido ligands, monoanionic bidentate and tridentate aryl amine ligands developed by van $\operatorname{Koten}^{7}$ has shown another path for mimicking the metallocene catalysts. However, to the best of our knowledge, there is no report of any metal halide, metal amide and/or metal alkoxide complexes containing anionic substituted pyrrole ligands. Though 2-(dimethylaminomethyl)pyrrole ${ }^{8}$ (DMAMPH) and 2,5-bis(dimethylaminomethyl)pyrrole (BDMAMPH) have been synthesized since 1947 , only a very few examples of complexes containing the bi-, and tri-dentate ligands have been reported. So far only one X-ray crystal structure, $\mathrm{Cr}(\mathrm{DMAMP})_{3}$ involving the monoanionic bidentate ligand has been determined. ${ }^{9} \mathrm{In}$ continuing our efforts of synthesizing metallocene-type metal complexes, we adopt the monoanionic substituted pyrrolate as auxiliary ligands for developing a system of early transition metal complexes applied in $\alpha$-olefin polymerization. Hence, here we report the preliminary results of synthesis and characterization of new zirconium complexes containing DMAMPH and BDMAMPH.

\section{RESULTS AND DISCUSSION}

Reaction of $\mathrm{Zr}\left(\mathrm{NEt}_{2}\right)_{4}$ with 2 equiv. of 2-(dimethylaminomethyl)pyrrole (DMAMPH) in heptane at room temperature by aminolysis, along with the elimination of $\mathrm{HNEt}_{2}$ generates $\mathrm{Zr}\left(\mathrm{NEt}_{2}\right)_{2}(\mathrm{DMAMP})_{2} \mathbf{1}$ in $85 \%$ yield as shown in Scheme I. Compound $\mathbf{1}$ is very air sensitive and decomposes immediately when exposed to air.

However, with the zirconium amide complex with 1 equiv. of DMAMPH, no isolable product was obtained, presumably due to the instability of the mono-aminolysis product, $\mathrm{Zr}\left(\mathrm{NEt}_{2}\right)_{3}$ (DMAMP), which undergoes disproportionation to yield zirconium amido and imido complexes. Crystals of 1 suitable for X-ray structure determination were obtained from a chilled $\left(-20{ }^{\circ} \mathrm{C}\right)$ saturated toluene solution. The air sensitive, colorless single crystal was mounted on a SMART CCD diffractometer and data were collected at $150 \mathrm{~K}$. The ORTEP, selected bond distances $(\AA)$ and angles $\left(^{\circ}\right)$ are shown in Fig. 1 and crystallographic data are summarized in Table 1.

Complex 1 adopts a distorted octahedral structure in which the zirconium atom is surrounded with two diethylamido ligands and two chelated DMAMP. Two DMAMP were chelated to a zirconium atom forming two constrained five 
Scheme I
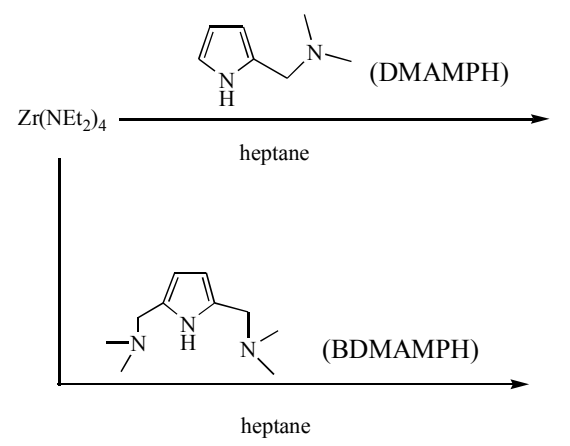

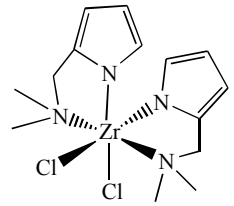

$\mathrm{ZrCl}_{2}(\mathrm{DMAMP})_{2}, \mathbf{3}$

$\mathrm{Me}_{3} \mathrm{SiCl} \uparrow$

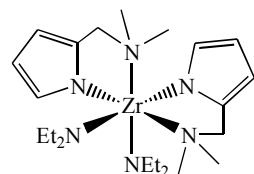

$\mathrm{Zr}\left(\mathrm{NEt}_{2}\right)_{2}(\mathrm{DMAMP})_{2}, 1$

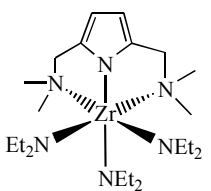

$\mathrm{Zr}\left(\mathrm{NEt}_{2}\right)_{3}(\mathrm{BDMAMP}), 2$

member rings with $\mathrm{N}(1)-\mathrm{Zr}-\mathrm{N}(2)$ and $\mathrm{N}(3)-\mathrm{Zr}-\mathrm{N}(4)$ of $71.05(7)^{\circ}$ and $70.37(7)^{\circ}$, respectively. It is interesting that the $\mathrm{N}(5)$ is trans to $\mathrm{N}(2)$ of dimethyl amino of one DMAMP while

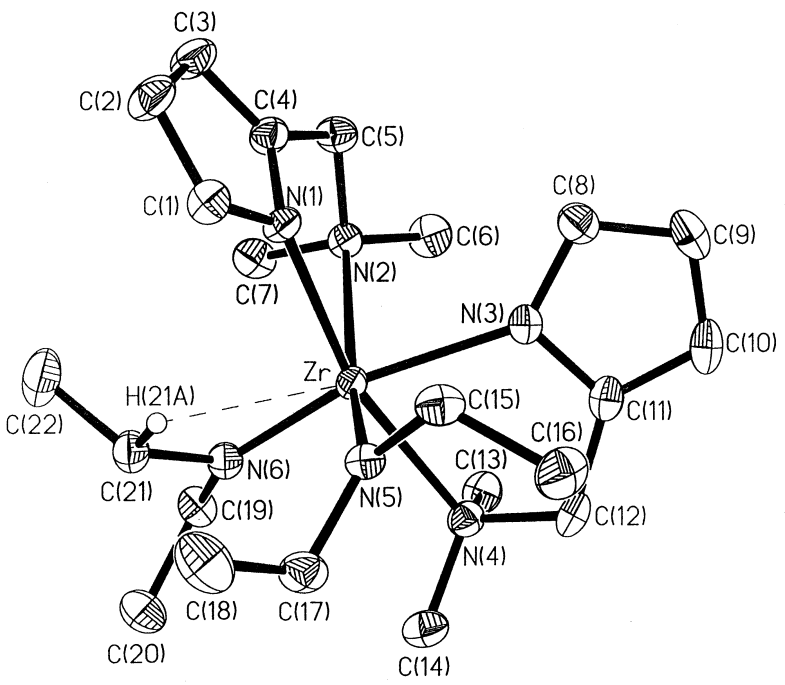

Fig. 1. The ORTEP of Complex 1, thermal ellipsoids are drawn at the $50 \%$ probability level and hydrogen atoms are omitted for clarity. Selected bond distances $(\AA)$ and angles $\left(^{\circ}\right)$ are as follows: $\mathrm{Zr}-\mathrm{N}(1)$ 2.206(2), Zr-N(2) 2.662(2), Zr-N(3) 2.233(2), $\mathrm{Zr}-\mathrm{N}(4)$ 2.524(2), Zr-N(5) 2.050(2), Zr-N(6) 2.063(2), Zr-C(21) 2.808(3), Zr-H(21A) 2.526(3), $\mathrm{N}(6)-\mathrm{Zr}-\mathrm{N}(3)$ 151.85(8), N(1)-Zr-N(4) 164.83(7), $\mathrm{N}(5)-\mathrm{Zr}-\mathrm{N}(2)$ 161.73(7), Zr-N(6)-C(21) 103.9(2), $\mathrm{Zr}-\mathrm{N}(5)-\mathrm{C}(15) 120.0(2)^{\circ}, \mathrm{Zr}-\mathrm{N}(5)-\mathrm{C}(17) 127.3(2)^{\circ}$, $\mathrm{Zr}-\mathrm{N}(6)-\mathrm{C}(19) 143.0(2)$.

Table 1. Crystallographic Data for Compound 1

\begin{tabular}{ll}
\hline Empirical formula & $\mathrm{C}_{22} \mathrm{H}_{42} \mathrm{~N}_{6} \mathrm{Zr}$ \\
Formula weight & 481.84 \\
Temperature & $150(1) \mathrm{K}$ \\
Wavelength & $0.71073 \AA$ \\
Crystal system & Monoclinic \\
Space group & $\mathrm{p} 2{ }_{1} / \mathrm{c}$ \\
Unit cell dimension & $a=10.0811(2) \AA$ \\
& $b=16.3462(1) \AA$ \\
& $c=15.5636(2) \AA$ \\
& $\beta=103.947(1)^{\mathrm{c}}$ \\
Volume, z & $2489.08(6) \AA^{3}, 4$ \\
Density (Calculated) & $1.286 \mathrm{Mg} / \mathrm{m}^{3}$ \\
Absorption coefficient & $0.461 \mathrm{~mm}{ }^{-1}$ \\
F(000) & 1024 \\
Crystal size & $0.30 \times 0.20 \times 0.20 \mathrm{~mm}$ \\
$\theta$ range for data collection & 1.84 to $26.39^{\circ}$ \\
Reflections collected & 11448 \\
Independent reflections & $4993\left(\mathrm{R}_{\text {int }}=0.0382\right)$ \\
Absorption correction & empirical used sadabs \\
Max. and min. transmission & 0.8944 and 0.8030 \\
Refinement method & Full-matrix least-squares on $\mathrm{F}^{2}$ \\
Data/restraints/parameters & $4993 / 0 / 263$ \\
Goodness-of-fit on $\mathrm{F}^{2}$ & 1.053 \\
Final R indices [I $>2 \sigma(\mathrm{I})]$ & $\mathrm{R} 1=0.0391, \mathrm{wR} 2=0.0741$ \\
R indices (all data) & $\mathrm{R} 1=0.0593, \mathrm{wR} 2=0.0803$ \\
Extinction coefficient & $0.0020(3)$ \\
Largest diff. Peak and hole & 0.326 and -0.371 e $\AA^{3}$ \\
\hline &
\end{tabular}

the $\mathrm{N}(6)$ is trans to $\mathrm{N}(3)$ of pyrrole of the other DMAMP. The $\mathrm{Zr} \cdots \mathrm{N}$ bond distances are consistent with the $\mathrm{Zr}$-amido $(\sigma$ bond) and $\mathrm{Zr}$-amine (coordinating bond) bond distances varying in the range of 2.05-2.23 $\AA$ and 2.52-2.66 $\AA$, respectively. Noteworthy, among the $\mathrm{Zr}$-amido bond distances, the diethylamido are bonded to zirconium atom more strongly than the pyrrolate nitrogen atoms do presumably due to the strong interaction of the amido nitrogen lone pair with the empty $d_{\pi}$ orbital of $\mathrm{Zr}$ forming partial $\mathrm{Zr}^{\cdots} \mathrm{NEt}_{2}$ double bonding. Interestingly, the bond angle of $\mathrm{Zr}-\mathrm{N}(6)-\mathrm{C}(21) 103.9(2)^{\circ}$ is much smaller than those of Zr-N(5)-C(15) $120.0(2)^{\circ}, \mathrm{Zr}-\mathrm{N}(5)-\mathrm{C}(17)$ $127.3(2)^{\circ}$, and $\mathrm{Zr}-\mathrm{N}(6)-\mathrm{C}(19) 143.0(2)^{\circ}$. In addition, the short bond distances of $\mathrm{Zr}-\mathrm{C}(21) 2.808$ (3) $\AA$ and $\mathrm{Zr}-\mathrm{H}(21 \mathrm{~A})$ 2.526(3) A suggesting that the complex 1 possesses an agostic interaction between $\mathrm{Zr}$ and $\mathrm{H}(21 \mathrm{~A})$ which is consistent with the results reported in the literature. ${ }^{10}$ Electron density of $\mathrm{H} 21 \mathrm{~A}$ and H21B were found in different Fourier maps. However, the $\mathrm{J}_{\mathrm{CH}}$ coupling constant of $\mathrm{C}(21)$ and $\mathrm{H}(21 \mathrm{~A})$ and $\mathrm{H}(21 \mathrm{~B}) 135 \mathrm{~Hz}$ is in the normal range of $\mathrm{sp}^{3}$ splitting suggesting the agostic interaction of $\mathrm{Zr}$ and $\mathrm{H}(21 \mathrm{~A})$ is no longer sustained in solution.

The ${ }^{1} \mathrm{H}$ NMR spectra of $\mathbf{1}$ are interesting, especially when compared with the solid-state structure which has been described in terms of a distorted octahedron with two amido 
ligands arranged in cis positions and trans to pyrrolate and dimethylamine, respectively. In $\mathrm{CDCl}_{3}$, a symmetrical structure resonance with 3.67 and $2.41 \mathrm{ppm}$ for the methylene and methyl group of DMAMP, respectively, and 3.56 and 0.86 ppm for the diethyl amido groups is observed. ${ }^{13} \mathrm{C}$-Gated and DEPT-135 NMR spectra also show the structure of complex 1 with the $\mathrm{J}_{\mathrm{CH}}$ of $\mathrm{CH}_{2} \mathrm{~N}$ and $\mathrm{NMe}_{2}$ of DMAMP at $134 \mathrm{~Hz}$ and 135 $\mathrm{Hz}$, respectively, which agrees with the $\mathrm{sp}^{3}$ hybridization of $\mathrm{C}-\mathrm{H}$ coupling constants. In order to resolve the dynamic property of complex 1 in solution, a variable temperature NMR experiment was held from $-60{ }^{\circ} \mathrm{C}$ to room temperature and the spectra are shown in Fig. 2. A characteristic feature of the VT- ${ }^{1} \mathrm{H}$ NMR spectra of $\mathbf{1}$ in $\mathrm{CDCl}_{3}$ at $-60{ }^{\circ} \mathrm{C}$ is the presence of four ethyl, four methyl, and six pyrrole signals. As noted in the description of the solid-state structure, the molecule has $\mathrm{C}_{1}$ symmetry and evidentially this is maintained in solution at
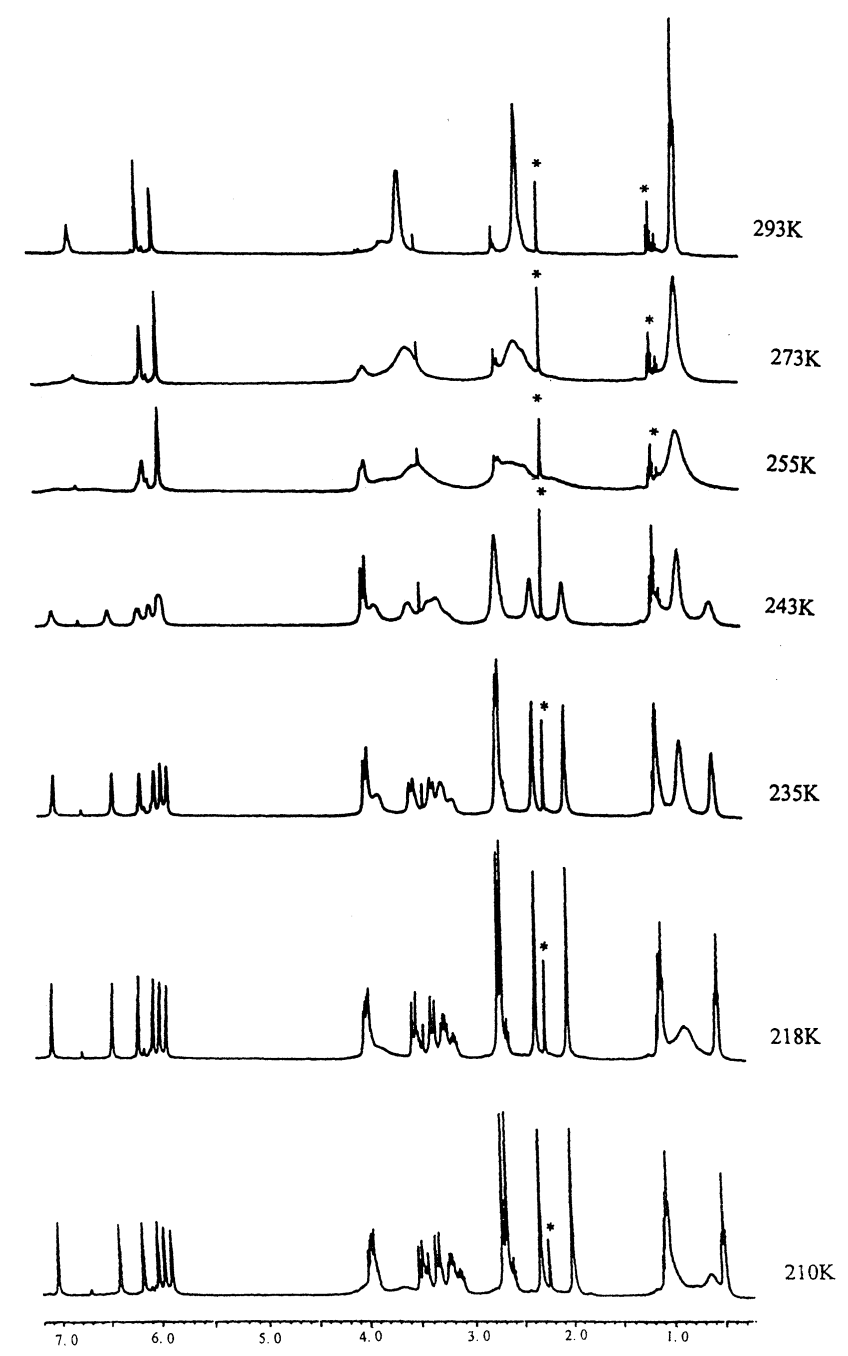

Fig. 2. VT NMR spectra of complex 1 in $\mathrm{CDCl}_{3}(400$ $\mathrm{MHz}$ NMR). Solvent impurities are marked with an asterisk. low temperature. On warming the $\mathrm{CDCl}_{3}$ solution of compound $\mathbf{1}$, the fluxionality of $\mathbf{1}$ is clearly observed and the ethyl groups are coalesced at $c a .248 \mathrm{~K}$ which gives a calculated activation energy of $\Delta \mathrm{G}^{\ddagger}=11 \mathrm{Kcal} / \mathrm{mole}^{12}$

Similarly, the reaction of $\mathrm{Zr}\left(\mathrm{NEt}_{2}\right)_{4}$ with 1 equiv. of 2,5-bis(dimethylaminomethyl)pyrrole (BDMAMPH) in heptane at $70{ }^{\circ} \mathrm{C}$ by aminolysis, along with the elimination of $\mathrm{HNEt}_{2}$ generates $\mathrm{Zr}\left(\mathrm{NEt}_{2}\right)_{3}$ (BDMAMP), gives 2 in $83 \%$ yield. The resulting complex $\mathbf{2}$ is a sticky liquid that can be solidified by cooling to liquid nitrogen temperature for a course of two hours. The ${ }^{1} \mathrm{H}$ and ${ }^{13} \mathrm{C}$ NMR spectra of 2 reveal a single set of diethyl amido resonance even at $60{ }^{\circ} \mathrm{C}$ suggesting a low energy barrier for the rotation of three diethylamido ligands in the octahedral structure even at low temperature. 2 is stable in $\mathrm{CDCl}_{3}$ at $-20{ }^{\circ} \mathrm{C}$ for several days but reacts with $\mathrm{CDCl}_{3}$ at room temperature within six hours forming (BDMAMP) $\mathrm{ZrCl}_{3}$, according to ${ }^{1} \mathrm{H}$ NMR spectroscopy. Reacting 1 with 2 equivalents of trimethylsilyl chloride in toluene at room temperature for a course of two hours followed by removing volatile to yield $\mathrm{ZrCl}_{2}$ (DMAMP) 3 in 75\%. Carefully controlling the amount of trimethylsilyl chloride is needed while adding excess resulting unisolable products. The ${ }^{1} \mathrm{H}$ NMR spectrum of $\mathbf{3}$ shows a characteristic pattern of dimethylaminomethyl at 2.86 and $4.24 \mathrm{ppm}$.

\section{CONCLUSIONS}

A new type of zirconium complexes containing substituted pyrrolate ligands has been synthesized and X-ray structure has been characterized. Using substituted pyrrolate as ligand in the early transition metal compounds has not been seen before and we believe the novel compounds have opened a new area regarding metallocene type chemistry. Expanding the reactions of resulting bi- and tri-dentate $\mathrm{Zr}$ compounds toward small organic molecules, such as olefin and polarized molecules, are currently proceeding, and related reactions such as compound $\mathbf{3}$ or $\mathbf{Z r C l}_{3}$ (BDMAMP) from $\mathrm{ZrCl}_{4}$ and their successive reactivity will be described in the near future.

\section{EXPERIMENTAL SECTION}

\section{General Procedure}

All the reactions were performed using standard Schlenk techniques in an atmosphere of high purity nitrogen or in a glove box. Ethyl ether was dried over $\mathrm{Na}$ /benzophenone ketyl and distilled before use. $\mathrm{Zr}\left(\mathrm{NEt}_{2}\right)_{4},{ }^{11} \mathrm{DMAMPH}$ and $\mathrm{BDMAMPH}^{8}$ were synthesized according to previously published reports in the literature. $\mathrm{CDCl}_{3}$ was degassed by using 
freeze-and-thaw and dried over $4 \AA$ molecular sieves. ${ }^{1} \mathrm{H}$ and ${ }^{13} \mathrm{C}$ NMR spectra were collected on a Bruker AC200 and VT NMR spectra were performed on a Bruker AC400 instrument. Elemental analysis was performed on a Perkin-Elmer CHN2400. All the compounds are extremely air sensitive; elemental analyses have been performed several times and the result of compound $\mathbf{1}$ is not in the error range and a ${ }^{1} \mathrm{H}$ NMR spectrum is included in the supplemental material.

\section{$\operatorname{Zr}\left(\text { NEt }_{2}\right)_{2}$ (DMAMP)2, 1}

A $100 \mathrm{~mL}$ Schlenk flask charged with $20 \mathrm{~mL}$ heptane and $\mathrm{Zr}\left(\mathrm{NEt}_{2}\right)_{4}$ (1 gram, 2.64 mmole) was added dropwise with a DMAMPH (0.654 gram, 5.27 mmole $)$ heptane $(20 \mathrm{~mL})$ solution at room temperature with stirring. Solution became cloudy and precipitation was formed during the reaction. Solvent was removed in vacuuo after 18 hours stirring and the resulting solid was recrystallized from toluene to generate 1.08 gram of white solid in $85 \%$ yield. ${ }^{1} \mathrm{H} \mathrm{NMR}\left(\mathrm{CDCl}_{3}\right): 6.75(\mathrm{~s}$, br), 6.06 (m), 5.89 (d), 3.67 (s, br), 3.53 (q), 2.41 (s), 0.86 (s).

${ }^{13} \mathrm{C} \mathrm{NMR}\left(\mathrm{CDCl}_{3}\right): 136.4(\mathrm{~s}), 128.0\left(\mathrm{~d}, J_{\mathrm{CH}}=180 \mathrm{~Hz}\right), 107.6$ $\left(\mathrm{d}, J_{\mathrm{CH}}=166 \mathrm{~Hz}\right), 103.5\left(\mathrm{~d}, J_{\mathrm{CH}}=165 \mathrm{~Hz}\right), 63.0\left(\mathrm{t}, J_{\mathrm{CH}}=137\right.$ $\mathrm{Hz}), 48.9\left(\mathrm{q}, J_{\mathrm{CH}}=141 \mathrm{~Hz}\right), 41.1\left(\mathrm{t}, J_{\mathrm{CH}}=135 \mathrm{~Hz}\right), 13.0\left(\mathrm{q}, J_{\mathrm{CH}}\right.$ $=126 \mathrm{~Hz})$.

\section{$\operatorname{Zr}\left(\text { NEt }_{2}\right)_{3}$ (BDMAMP), 2}

A $100 \mathrm{~mL}$ Schlenk flask charged with $20 \mathrm{~mL}$ heptane and $\mathrm{Zr}\left(\mathrm{NEt}_{2}\right)_{4}$ (2 gram, 5.28 mmole) was added dropwise with a BDMAMPH (0.956 gram, $5.28 \mathrm{mmole})$ heptane $(20 \mathrm{~mL})$ solution at room temperature with stirring. The resulting solution was heated to $80^{\circ} \mathrm{C}$ for 20 hours and solvent was removed in vacuuo to yield an off-white sticky solid. White crystals were isolated in $83 \%$ yield (2.2 grams). ${ }^{1} \mathrm{H}\left(\mathrm{C}_{6} \mathrm{D}_{6}\right): 6.35$ (s), $3.60(\mathrm{~s}), 3.42(\mathrm{q}), 2.14(\mathrm{~s}), 1.10(\mathrm{t}) .{ }^{13} \mathrm{C}\left(\mathrm{C}_{6} \mathrm{D}_{6}\right): 137.7(\mathrm{~s})$, $108.0\left(\mathrm{~d}, J_{\mathrm{CH}}=165 \mathrm{~Hz}\right), 59.6\left(\mathrm{t}, J_{\mathrm{CH}}=133 \mathrm{~Hz}\right), 46.6\left(\mathrm{q}, J_{\mathrm{CH}}=\right.$ $130 \mathrm{~Hz}), 43.4\left(\mathrm{t}, J_{\mathrm{CH}}=131 \mathrm{~Hz}\right), 15.9\left(\mathrm{~d}, J_{\mathrm{CH}}=125 \mathrm{~Hz}\right)$. Anal. Calcd. for $\mathrm{C}_{22} \mathrm{H}_{48} \mathrm{~N}_{6} \mathrm{Zr}$ : C, 54.16; H, 9.92; N, 17.23. Found: C, 54.61; H, 8.82; N, 16.25.

\section{$\mathrm{ZrCl}_{\mathbf{2}}$ (DMAMP), 3}

A $50 \mathrm{~mL}$ Schlenk flask charged with $20 \mathrm{~mL}$ toluene and 1 (0.475 gram, 0.99 mmole) was added dropwise with $\mathrm{Me}_{3} \mathrm{SiCl}(0.25 \mathrm{~mL}, 2$ mmole) at room temperature with stirring. The resulting solution was stirred for 2 hours and volatiles were removed in vacuuo to yield 0.301 gram $(75 \%$ yield) of off white solid. ${ }^{1} \mathrm{H}$ NMR $\left(\mathrm{CDCl}_{3}\right): 6.69(\mathrm{~m}), 6.03$ (m), $5.96(\mathrm{~m}), 4.24(\mathrm{~s}), 2.86(\mathrm{~s}) .{ }^{13} \mathrm{C} \mathrm{NMR}\left(\mathrm{CDCl}_{3}\right): 136.4(\mathrm{~s})$, $128.4\left(\mathrm{~d}, J_{\mathrm{CH}}=183 \mathrm{~Hz}\right), 109.0\left(\mathrm{~d}, J_{\mathrm{CH}}=168\right), 104.2\left(\mathrm{~d}, J_{\mathrm{CH}}=\right.$ $168 \mathrm{~Hz}), 63.3\left(\mathrm{t}, J_{\mathrm{CH}}=140 \mathrm{~Hz}\right), 47.7\left(\mathrm{q}, J_{\mathrm{CH}}=138 \mathrm{~Hz}\right)$. Anal. Calcd. for $\mathrm{C}_{14} \mathrm{H}_{22} \mathrm{~N}_{4} \mathrm{ZrCl}_{2}$ : C, 41.17; $\mathrm{H}, 5.43 ; \mathrm{N}, 13.72$. Found: C, 39.38; H, 5.55; N, 12.21.

\section{X-Ray Structure Determination of Compound 1}

The crystal was mounted on a glass fiber using epoxy resin and transferred to a goniostat and cooled to $150 \mathrm{~K}$ under liquid nitrogen vapor. Data were collected on a Bruker SMART CCD diffractometer with graphite-monochromated Mo $\mathrm{K}_{\alpha}$ radiation. Structural determinations were made using the SHELXTL package of programs. All refinements were carried out by full-matrix least squares using anisotropic displacement parameters for all non-hydrogen atoms. All the hydrogen atoms are calculated. A different Fourier Map was taken and the electron density of H21A and H21B were both found. The crystal data are summarized in Table 1 .

\section{ACKNOWLEDGMENT}

We thank the National Science Council of Taiwan for financial support and the National Center for High-Performance Computing for database searching.

\section{Supporting Information Available}

${ }^{1} \mathrm{H}$ NMR spectrum and tables of crystal data for $\mathbf{1}$ including tables of hydrogen coordinates, and $U$ values, bond lengths, bond angles, anisotropic parameters, and data collection parameters (18 pages). Ordering information is given on any masterhead page.

Received March 27, 2000.

\section{Key Words}

2-(Dimethylaminomethyl)pyrrolate and 2,5-bis(dimethylaminomethyl)pyrrolate; Zirconium complexes; Pyrrole; Zirconium amide; Metallocene.

\section{REFERENCES}

1. For reviews see (a) Jordan, R. F. Adv. Organomet. Chem. 1991, 32, 325. (b) Brintzinger, H. H.; Fischer, D.; Mülhaupt, R.; Rieger, B.; Waymouth, R. M. Angew. Chem. Int. Ed. Engl. 1995, 34, 1143. (c) Möhring, P. C.; Coville, N. J. J. Organomet. Chem. 1994, 479, 1.

2. (a) van der Linden, A.; Schaverien, C. J.; Meijboom, N.; Ganter, C.; Orpen, A. G. J. Am. Chem. Soc. 1995, 117, 3008. (b) Sernetz, F. G.; Mülhaupt, R.; Fokken, S.; Okuda, J. Macromol. 1997, 30, 1562. (c) Gielens, E. E. C. G.; Tiesnitsch, J. Y.; Hessen, B.; Teuben, J. H. Organometallics 1998, 17, 1652. (d) Bei, X.; Swenson, D. C.; Jor- 
dan, R. F. Organometallics 1997, 16, 3282.

3. (a) Shah, S. A. A.; Dorn, H.; Voigt, A.; Roesky, H. W.; Parisini, E.; Schmidt, H. G.; Noltemeyer, M. Organometallics 1996, 15, 3176. (b) Warren, T. W.; Schrock, R. R.; Davis, W. M. Organometallics 1996, 15, 562. (c) Tinkler, S.; Deeth, R. J.; Duncalf, D. J.; McCamley, A. Chem. Commun. 1996, 2623. (d) Scollard, J. D.; McConville, D. H. J. Am. Chem. Soc. 1996, 118, 10008. (e) Gibson, V. C.; Kimberley, B. S.; White, A. J. P.; Williams, D. J.; Howard, P. Chem. Commun. 1998, 313. (f) Horton, A. D.; de With, J.; van der Linden, A. J.; van de Weg, H. Organometallics 1996, 15, 2672. (g) Schattenmann, F. J.; Schrock, R. R.; Davis, W. M. Organometallics 1998, 17, 989. (h) Hagadorn, J. R.; Arnold, J. J. Chem. Soc. Dalton Trans. 1997, 3087. (i) Uhrhammer, R.; Black, D. G.; Gardner, T. G.; Olsen, J. D.; Jordan, R. F. J. Am. Chem. Soc. 1993, 115, 8493.

4. Vollmerhaus, R.; Shao, P.; Taylor, N. J.; Collins, S. Organometallics 1999, 18, 2731.

5. Baumann, R.; Davis, W. M.; Schock, R. R. J. Am. Chem.
Soc. 1997, 119, 3830.

6. Britovsek, G. J. P.; Gibson, V. C.; Wass, D. F. Angew. Chem. Intl Ed. 1999, 38, 428.

7. Gossage, R. A.; van de Kuil, L. A.; van Koten, G. Acc. Chem. Res. 1998, 31, 423.

8. (a) Herz, W.; Dittmer, K. J. Am. Chem. Soc. 1947, 69, 1698. (b) Kim, H.; Elsenbaumer, R. L. Tetrahedron Letters. 1998, 39, 1087.

9. Drvs, H.; Schmeiber, A.; Hartung, H.; Baumeister, U. Chem. Ber. 1996, 129, 853.

10. (a) Scholz, J.; Rehbaum, F.; Thiele, K. H.; Goddard, R.; Betz, P.; Kruger, C. J. Organomet. Chem. 1993, 443, 93. (b) Jeon, Y.-M.; Heo, J.; Lee, W. M.; Chang, T.; Kim, K. Organometallics 1999, 18, 4113.

11. Bradley, D. C.; Thomas, I. M. J. Chem. Soc. 1960, 3857.

12. Data calculated from ${ }^{1} \mathrm{H}$ NMR spectra (400 MHz NMR) using the chemical shift differences of the proton resonances in the slow exchange limits. See reference in Friebolin, H. Basic one- and two-dimensional NMR spectroscopy, VCH 1991. 